\title{
Il caso della città di Shibam nello Yemen del Sud. Conoscenza e monitoraggio avanzato del patrimonio culturale
}

\author{
Gaetano Ginex \\ Francesco Trimboli \\ Sonia Mercurio
}

Abstract

II lavoro presentato è strettamente legato al tentativo di applicare e sperimentare le tecniche del disegno e della modellazione digitale finalizzate alla conoscenza e alla salvaguardia del patrimonio culturale, con l'obiettivo di riflettere su come, in architettura, il segno sia l'espressione tangibile del processo diagnostico che porta all'essenza delle cose; disvelatore di verità, di forme prima di divenire morfologie. Lo studio si focalizza sulla trama morfologica della città di Shibam, nell'area dello Yemen del Sud, archetipo formale che, nella integrazione delle sue parti, è uno tra gli esempi più iconici del sistema architetturale contemporaneo. In riferimento agli Obiettivi definiti dall'Agenda 2030, il tema si legata all'Obiettivo I I: "Creare città e insediamenti umani inclusivo, sicuro, duraturo e sostenibile" e in particolare all'Obiettivo I |.4: "Rafforzare gli impegni per proteggere e salvaguardare i beni culturali del mondo e del patrimonio naturale". In questa ottica il processo metodologico adottato, indice all'utilizzo di attrezzature con scopi archeologici e architettonici per il rilievo delle città murate e fortezze in aree pericolose, il cui obiettivo generale è quello di restituire l'identità dei popoli.

Parole chiave

archetipo, rilievo, morfologia urbana, monitoraggio, patrimonio.

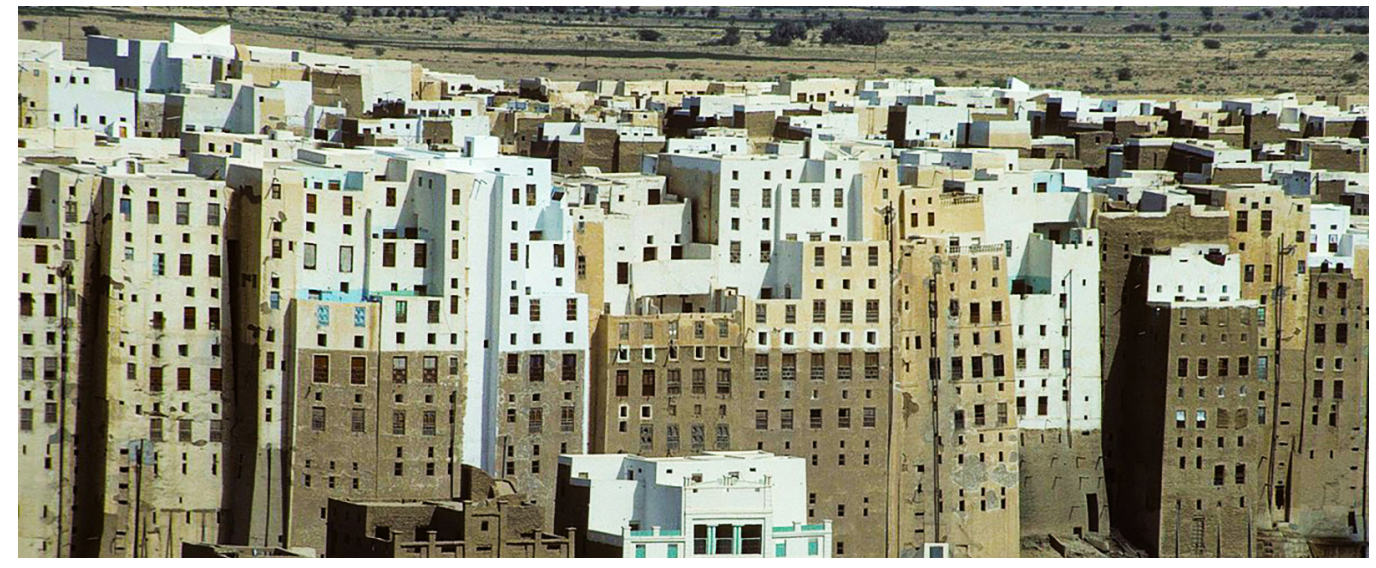




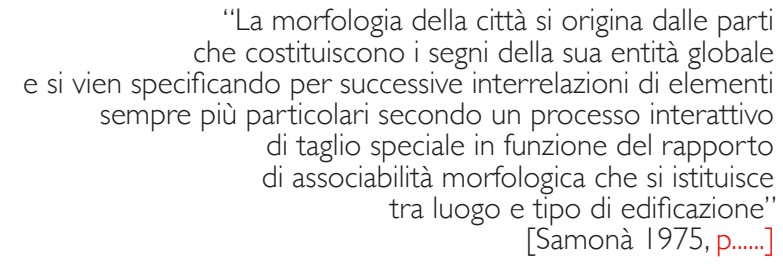

II lavoro presentato [I] riguarda il ri-disegno dei caratteri architettonici principali e lo studio dei processi costitutivi e delle invarianti morfologiche presenti nelle città costruite in prossimità di ambienti particolarmente sensibili e soggetti ad eventi bellici che ne compromettono la continuità, con particolare riferimento alla città di Shibam nell'area dello Yemen del Sud. II nostro obiettivo è stato quello di sperimentare ed applicare tecniche di disegno digitale finalizzate alla conoscenza e alla salvaguardia di architetture in ambiente desertico, di elevato interesse culturale mediante la ricostruzione digitale in territori dove le rilevazioni in presenza risultano difficoltose e per varie ragioni a rischio. II tessuto urbano della città di Shibam ha una configurazione morfologica di alto valore figurativo. È un'immagine fragile per la sua integrità morfologica e fisiognomicamente rappresenta una forma di saggezza umana. Lo studio si fonda sul mettere in evidenza questa bellezza complessa articolata storicamente come 'archetipo formale' come principio insediativo stabile, immutabile ed universale. Maestosa per le sue architetture e la sua posizione è la struttura urbana in cui è evidente il tentativo di sopravvivenza che, come tutte le civiltà formatesi a contatto con il deserto, sono improntate sulla necessità quasi biologica di circoscrivere lo 'spazio di appropriazione' all'interno di un recinto che nell'Islam diventa matrice figurativa dell'architettura, della città e del territorio. La struttura del centro abitato va continuamente svelata così da rivelare attraverso sezioni, profili, piante, modelli digitali, oltre le varianti anche le omogeneità e stratificazioni avvenute nel tempo che identificano alla fine del processo di lettura e rappresentazione una immagine definita come 'icona' [2] ovvero come immagine profonda che colloca il sistema spaziale di Shibam dentro un insieme di significati formali e sostanziali che si coagulano nell'immagine definitiva della città [Ajroldi 20 I4]. L'impianto morfologico unitario è costituito dal tessuto edilizio e dal tessuto dei vuoti condivisi nella loro complementarietà dal magma delle tipologie. Una commistione di spazi vuoti e pieni, "intimi”" sistemi di spazio costruito, che disvelano i rapporti di dipendenza morfologica e tipologica che gli elementi architettonici ai vari livelli di organizzazione hanno tra loro. Tutti gli elementi architettonici si presentano nel sistema di spazi costruiti compatti e solidali tra loro. La tipologia conserva l'integrità essenziale e originaria quasi archetipica delle relazioni di solidarietà tra i sistemi di spazio che si susseguono nello sviluppo della morfologia. La morfologia a sua volta si configura come un insieme di relazioni spaziali legate da interdipendenza in un insieme topologicamente orientato [Petruccioli 2007]. È così infatti che tutte le architetture presenti contribuiscono a creare nella loro integrazione una realtà morfologica urbana e una immagine di città iconicamente e universalmente riconoscibile.

\section{Disegno, la Rappresentazione}

Siamo partiti dall'analisi dei caratteri costitutivi e dei rapporti geometrico-spaziali delle piccole morfologie dei tessuti urbani, identificandone parti morfologiche coerenti tra loro, elementi architettonici e invarianti, decostruendo il sistema unitario per poi ricomporlo come sistema unico. Si sono messe così in evidenza le stratificazioni e le trasformazioni morfologiche avvenute nel tempo sempre con un'attenzione particolare al tessuto abitativo tradizionale della Medina. La ricerca ha infine tentato di individuare, alla scala delle singole abitazioni, i loro caratteri distintivi così da ricostruirne l'identità fisiognomica attraverso un 'modello' digitale che ne restituisse un complessivo significato spaziale sociale e culturale. Ciò è stato possibile attraverso lo studio della struttura fisica generale dell'impianto, lo studio dei volumi, lo studio della forma complessiva decostruendola in unità minime come configurazioni 'dinamiche' analizzate come geometrie formali di insiemi minimi intesi come 
modelli di parti urbane, al fine di ricondurli a forme complessive in un habitat inteso come 'ambiente totale'. II disegno analizza questa particolare condizione attraverso un approccio attento all'opera totale come 'documento' che diventa tale attraverso la misurazione e la restituzione digitale dei dati che definiscono tutti gli spazi architettonici della città. L'obiettivo raggiunto nella restituzione digitale del modello della città, mette in evidenza il rapporto che esiste tra l'organizzazione della 'forma' base, la casa, il dar al Islam, il particolare impianto tipologico che si sviluppa in altezza che costruisce il 'morpho-logos' e il resto del costruito, identificandone i caratteri ripetitivi che alla fine del processo di crescita 'costruiscono' l'immagine unica e unitaria della città, in un rapporto continuo tra forma semplice e immagine complessiva dell'impianto urbano racchiusa all'interno di un recinto idealmente "eterno" e invalicabile.

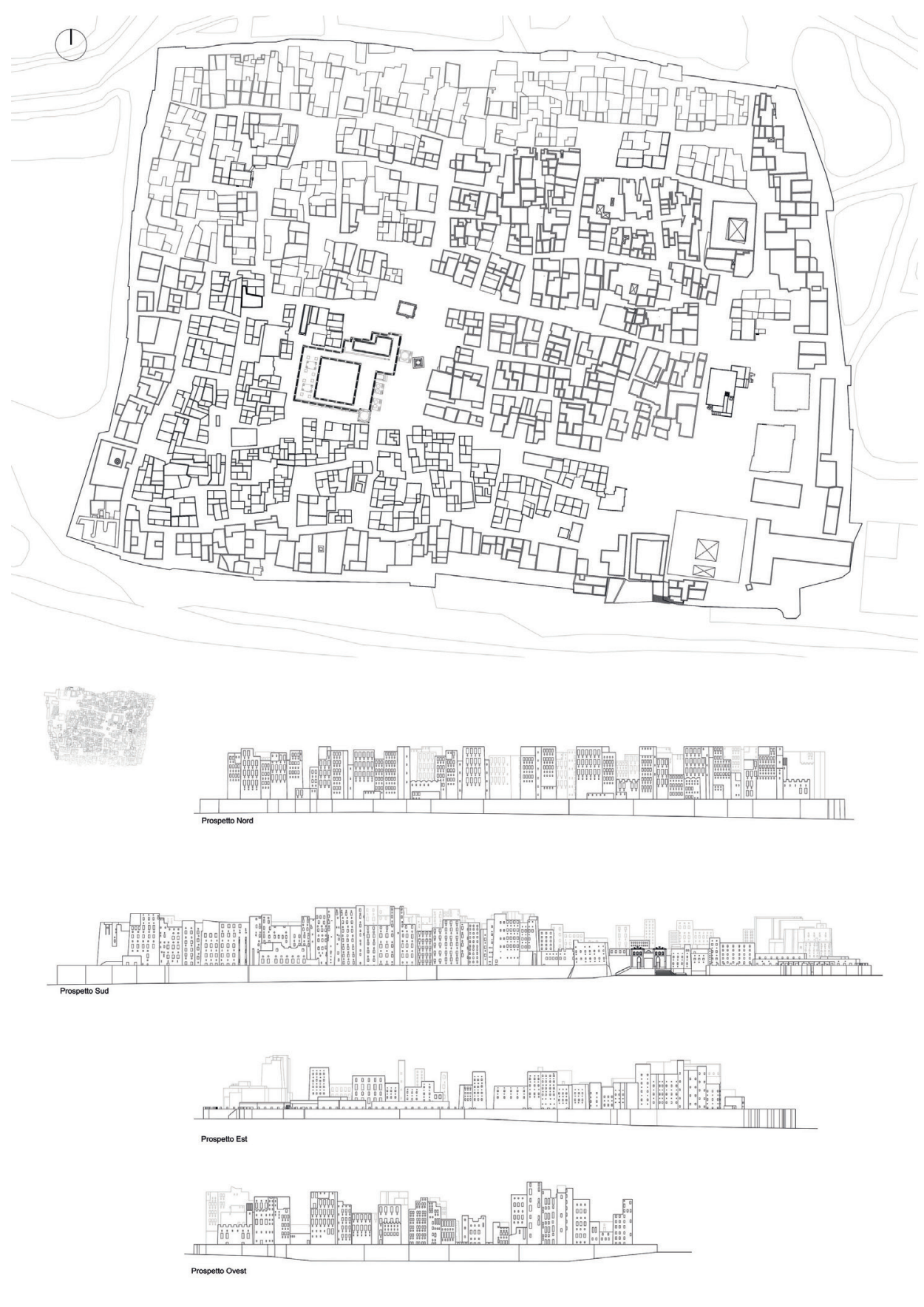


Fig. 2. Assonometrie esplose della città $d$ Shibam.
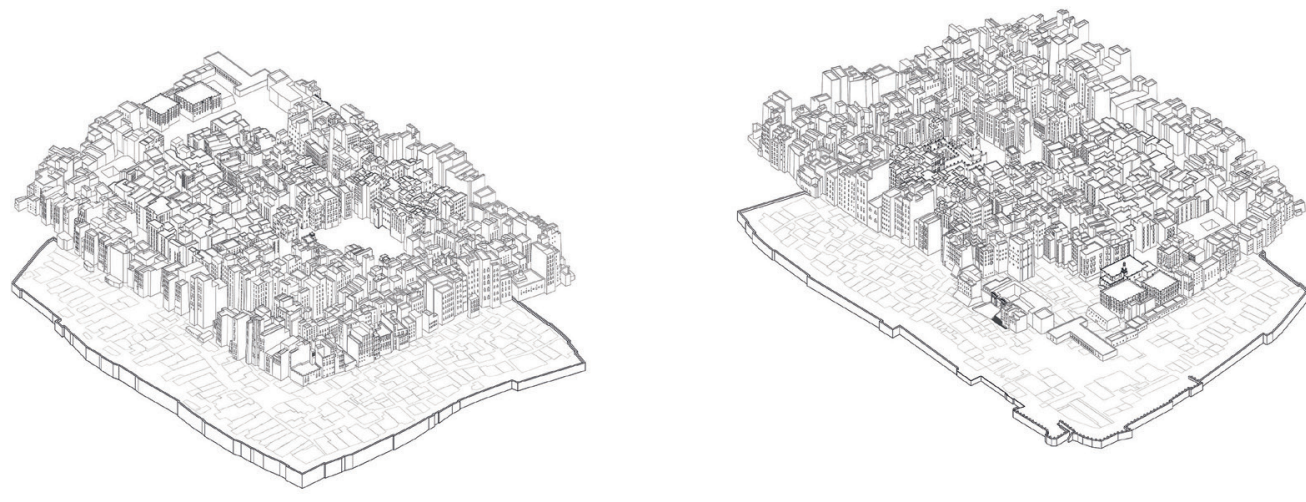

\section{Morfologie dal fango}

L'eccezionale valore universale riconosciuto dall'Unesco alla città di Shibam, restituisce solo in parte la rarità di questo impianto urbano. Shibam, la città di fango, sembra uno di quei luoghi impossibili, un'interruzione della trama desertica che dà luogo ad una straordinaria quanto complessa morfologia urbana.

Ė certamente, tra i più antichi e meglio conservati esempi di pianificazione urbana basata su un principio aggregativo che ha generato un sistema ad alta densità urbana, definito, però, secondo l'asse della verticalità, piuttosto che dell'orizzontalità.

Abbarbicata su uno sperone di roccia del Wadi Hadramaut, la città costruita "da mani di giganti per antichi re simili a dei" [Freya 1936, p. I85], si è sviluppata su una pianta pressoché rettangolare, fortificata da un muro di circa 330 metri di lunghezza per 240 metri di larghezza; tali peculiarità morfologiche hanno limitato spazio di espansione all'interno, ma le hanno garantito una prima linea difensiva dagli attacchi beduini. Questa sua origine difensiva si manifesta anche nella densa organizzazione degli edifici, nella compattezza di questi, oltre che nella frammentazione dello spazio pubblico, che appare quasi residuale, un labirinto di vicoli e slarghi.

La contiguità di case-torri crea delle passerelle in altezza che fungono da collegamento in caso di attacco nemico e restituiscono, alla vista zenitale, una fitta e complessa trama ad alto impatto visivo che ha come skené la vastità del deserto, 'luogo' basamentale per tutti gli insediamenti studiati, in cui architettura e natura si fondono in un unico sistema urbano [Ginex 20 I7].
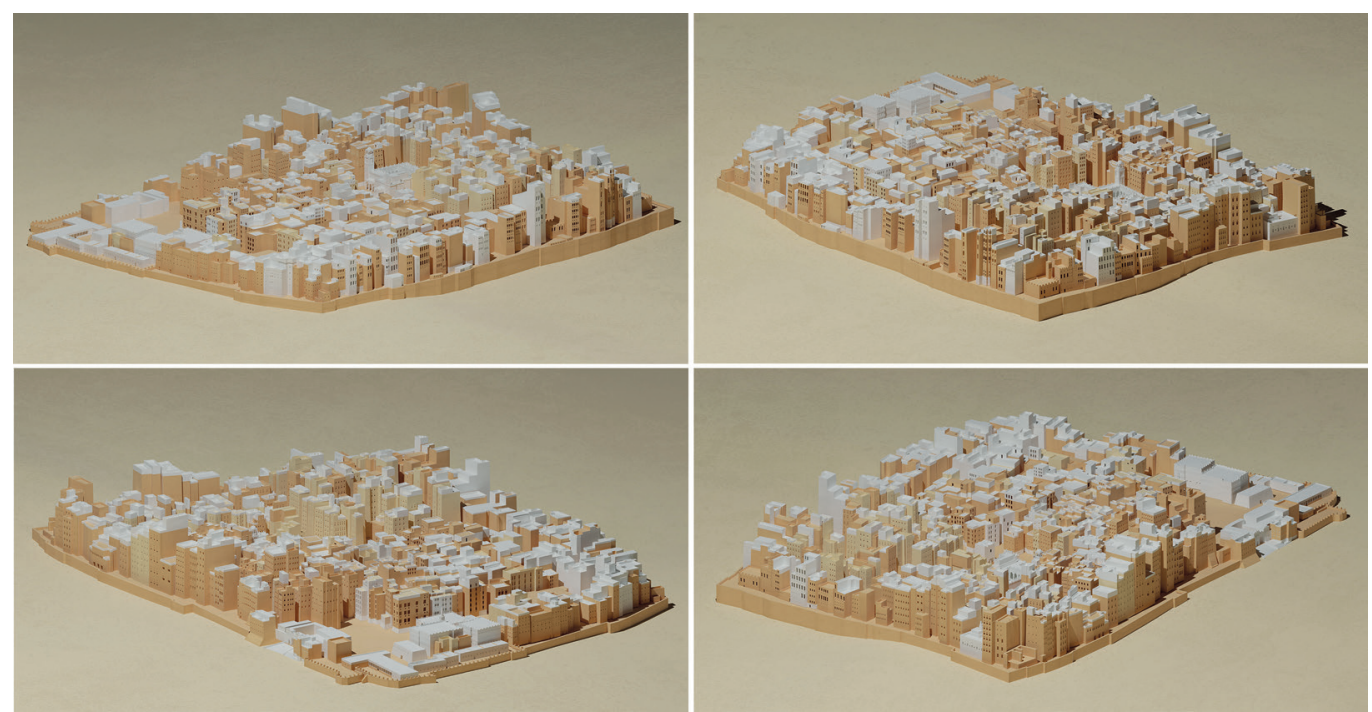

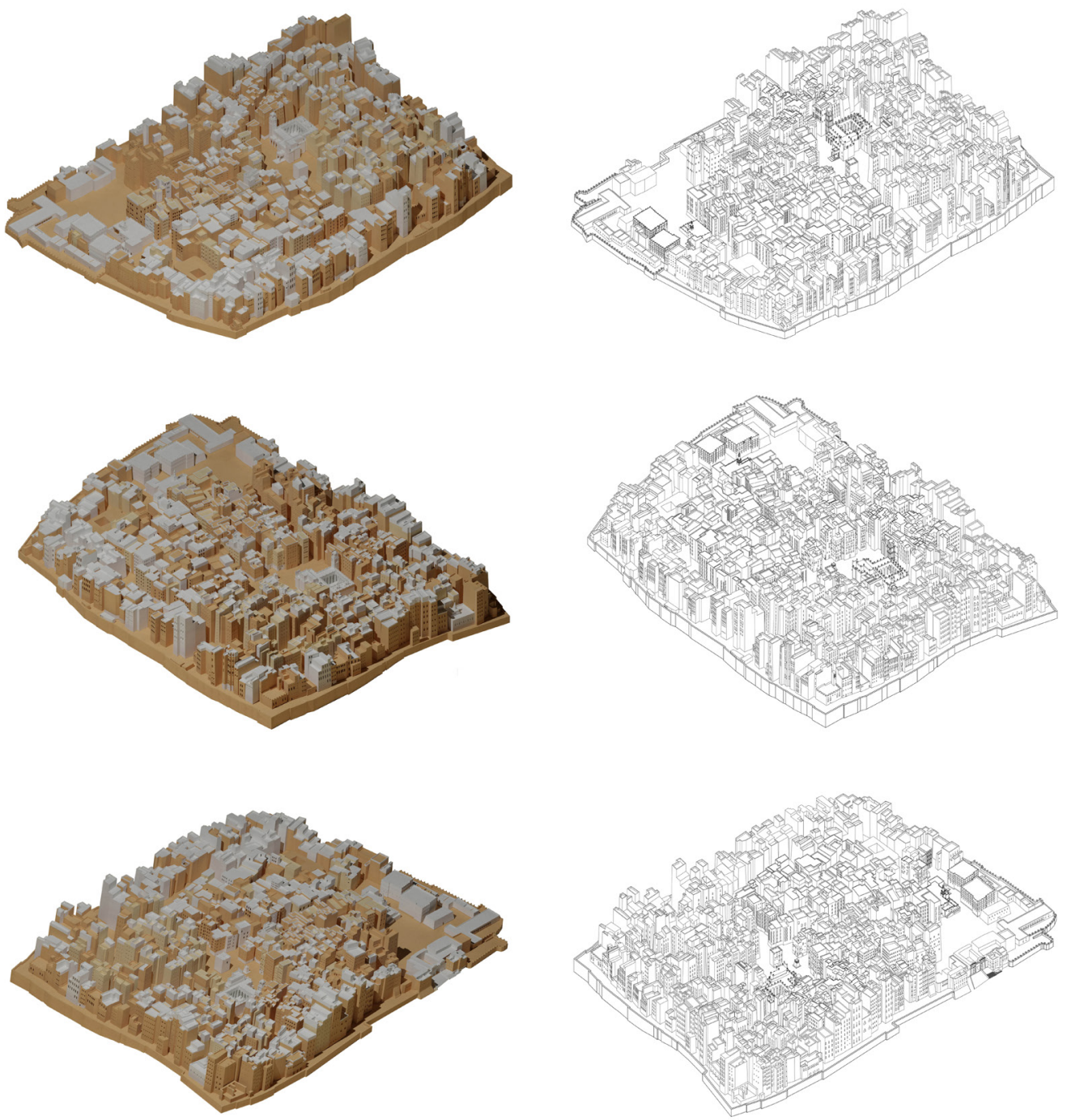

Fig. 4. Assonometrie
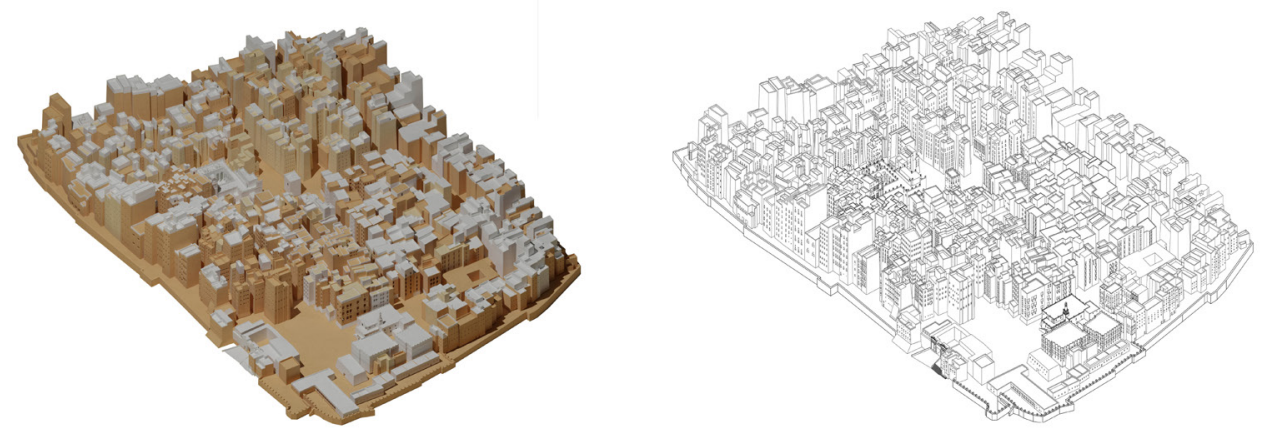
II tentativo di studiare i processi aggregativi e compositivi del tessuto abitativo e comprendere i meccanismi generativi, ha permesso di individuare gli elementi urbani che definiscono la città di Shibam, in tale maniera:

I. La trama viaria fatta di vicoli e cul-de-sac, che, più che definire, viene definita dall'edificato; 2. II confine tra pubblico e privato, molto labile, con inviluppo in altezza, anch'esso;

3. Lo spazio pubblico aperto a tutti, un diaframma di luoghi di piccole e grandi dimensioni che si compone o si frammenta a seconda dello sviluppo della città;

4. Le tipologie 'speciali' all'interno delle mura della città tra cui: sei moschee; due madrase (scuole); uno zawiya privato (luogo di residenza o di riunione dei sufi); due palazzi pubblici; la porta della città; una clinica sanitaria; un complesso amministrativo composto da quattro edifici. Dal punto di vista tipologico, in riferimento al tessuto residenziale, ritroviamo dei caratteri comuni ad ogni edificio, che risulta in genere occupato da una sola famiglia. II primo e il secondo piano di questo, sono solitamente destinati a stalla per animali, deposito di cibo, o come negozio, luogo della relazione e dello scambio con l'esterno. A questo livello non vi è quasi alcuna fenestrazione, o ve ne sono di modiche dimensioni, con conseguenti problemi di ventilazione; questo è testimonianza simbolica della forte competizione che esisteva tra le famiglie rivali di questa regione.

I livelli successivi delle torri segnano la transizione dal pubblico al privato. || primo piano ospita una o più sale principali (mahadir), un ambito essenzialmente maschile. Al piano successivo, si trova la sala delle riunioni di famiglia, che talvolta viene anche utilizzata come camera da letto, e sopra ancora, le camere private, compresa la cucina, spazio generalmente destinato alle donne. L'ultimo piano, o mafrah, è riservato agli incontri con parenti o amici. Le superfici finestrate aumentano ai livelli superiori dell'edificio, fino a giungere alle terrazze, completamente percorribili, dove viene compensata l'assenza di cortili aperti al piano terra. Queste case-torri hanno a coronamento delle merlature e nella maggior parte dei casi, questi merli assumono forme decorative e si imbiancano con calce, oltre ad ottemperare alle necessità difensive.

La sezione di questi 'edifici di fango' è trapezoidale, infatti, le pareti portanti, diminuiscono il loro spessore con lo sviluppo in altezza dell'edificio stesso.

Le facciate, molto fragili poiché esposte a fattori quali il vento e la pioggia, necessitano di una manutenzione continua che contrasti il processo erosivo e vengono ripetutamente ripristinate negli intonaci fangosi.

Shibam è, di fatto, l'archetipo che genera la modernità, un sistema primo e assoluto, che contiene i caratteri della città islamica sebbene sia preislamica, che precede lo sviluppo verticale della città moderna del XX secolo, che mantiene la sua conformazione originaria intra moenia, deferente verso quella ancestrale distesa di sabbia

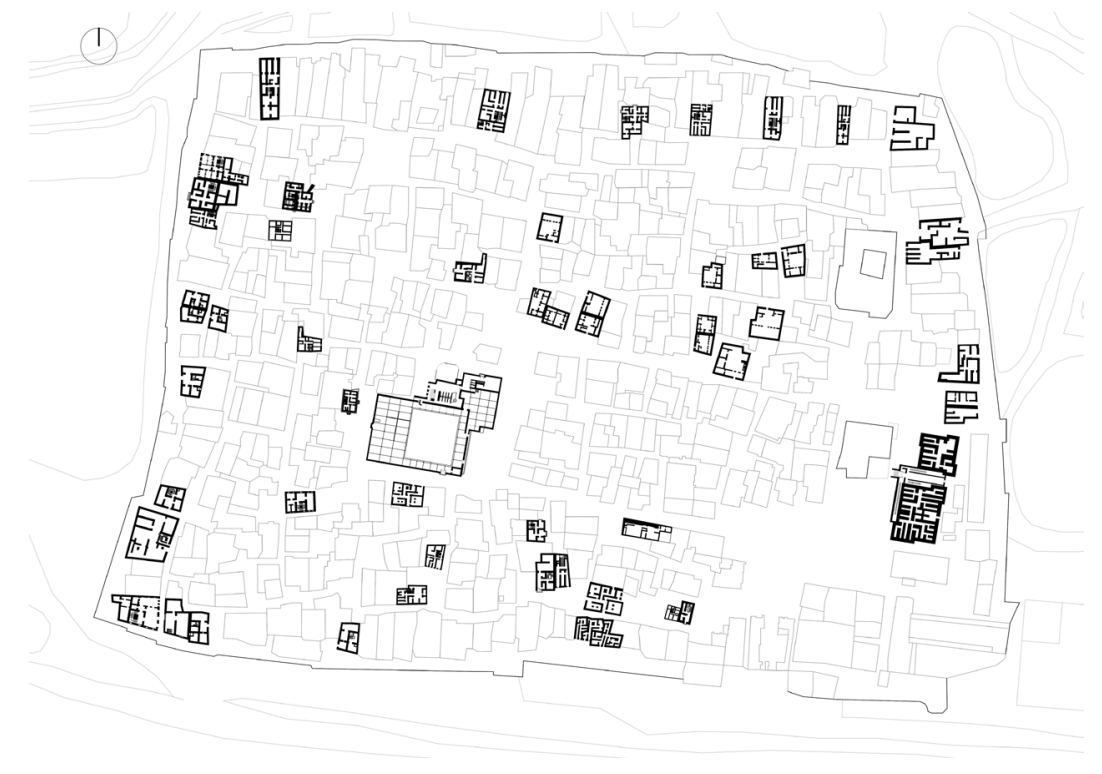



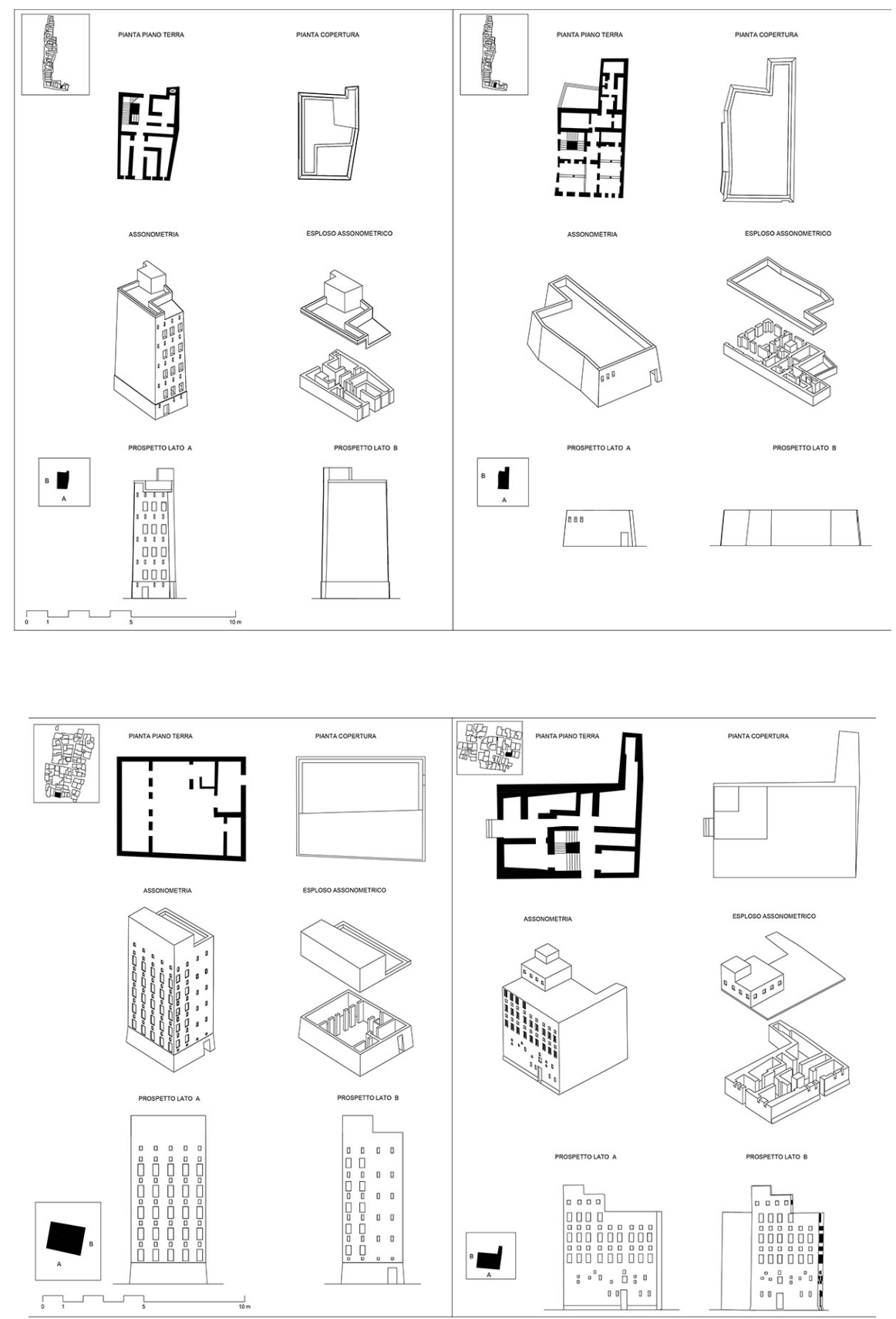

\section{Prototipi Urbani. II Rinascimento tecnologico della Rappresentazione}

Nello scenario contemporaneo, in architettura, il modello, se pur tecnologicamente evoluto nelle tecniche di realizzazione, diviene l'unico mezzo e strumento con cui straniare e riconoscere l'essenza delle cose, vedere oltre il visibile, oltre la dimensione illusoria di uno schermo, limite tra il saper fare e il saper vedere.

In questa ottica, l'innovazione tecnologica, in architettura è riferita all'applicazione ottimale dei principi e dei processi che ne governano la produzione, divenendo il mezzo con cui trasferire la conoscenza, intesa come la capacità di governare e gestire le avanguardie di un nuovo Rinascimento tecnologico. "Con il computer si è precisi, ma non si arriva all'essenza delle cose" [Gregotti 2017] [3]. La conseguenza è che si viri ad una maggiore qualità e scientificità dei processi, che, se pur rappresentando l'evoluzione della tecnica, è comunque 


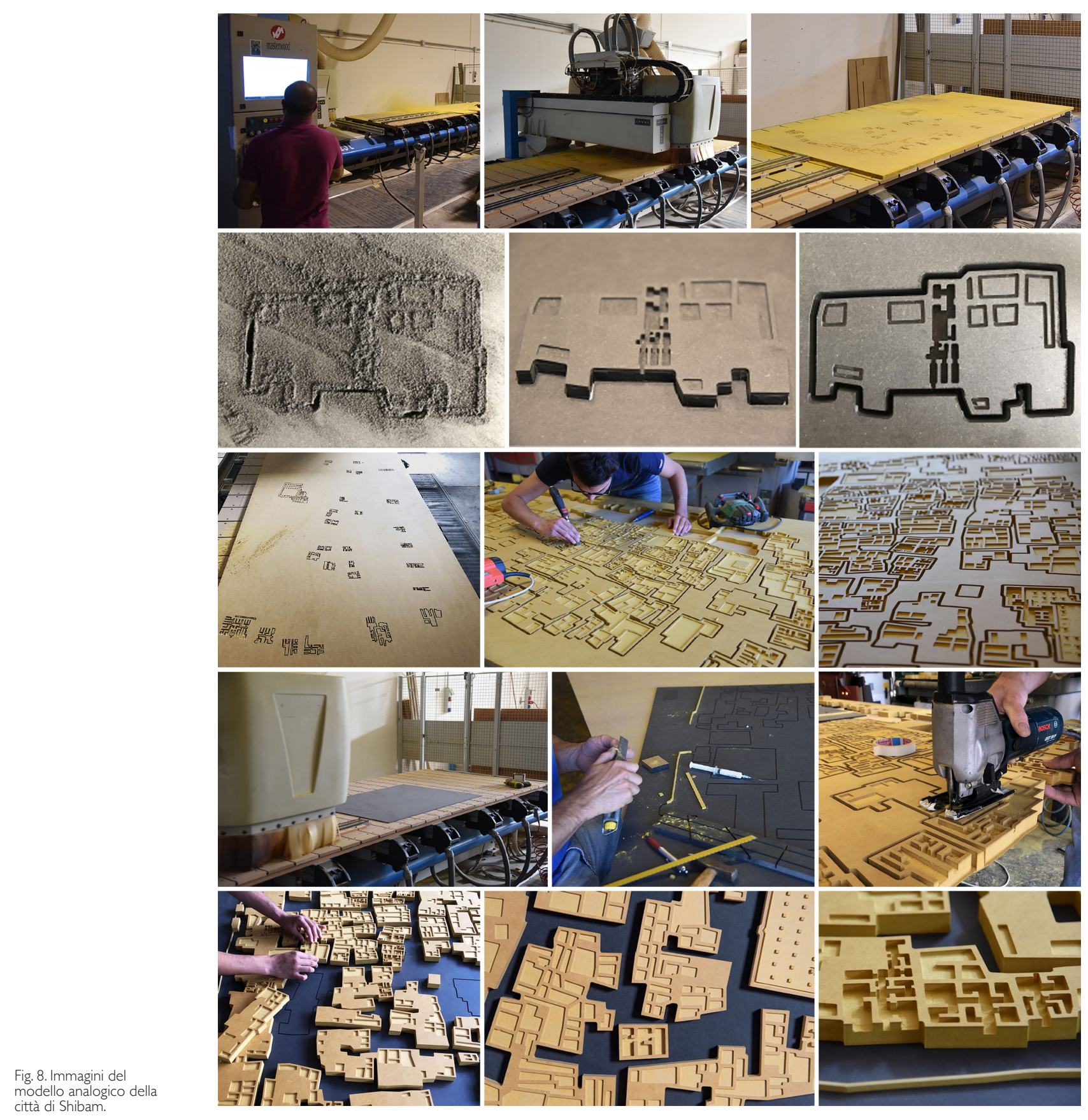


un processo meccanico dato dalla manipolazione di dati, di numeri che fanno riferimento ad una azione, ad un gesto che attiene alle dita: 'digitare' [4]. L'analisi etimologica della parola tecnologia, techne e loghía si riferisce al saper fare, dove la techne attiene la manualità, l'azione e la loghía alla razionalizzazione del processo che porta all'azione stessa. Da questa analisi, appare interessante osservare come spesso, in architettura, la tecnologia è sinonimo di digitale, al quale si riconosce erroneamente il confine tra conoscenze pratiche e conoscenze teoriche, pertanto, la manipolazione tattile di qualsiasi processo informatico, digitale, tende a sovrapporsi a quello monodirezionale della creatività.

Nel dualismo analogico-digitale, inteso il primo come techne ed il secondo come loghía, la ricerca sulla Rappresentazione in Architettura, e sul Disegno in generale, intende fare luce sulle potenzialità offerte dalle attuali tecnologie, che seppur innovative, devono riferirsi al gesto primitivo della comunicazione: il segno (esso digitale o analogico). Non a caso quindi, il riferimento ad un Nuovo Rinascimento, allude al fatto che è appunto in questa epoca, che il segno acquisisce identità culturale prima di divenire Architettura, facendosi modello, maquette, plastico, espressione tangibile della contaminazione tra il sapere ed il saper fare, divenendo la materializzazione fisica di una idea.

Il lavoro su Shibam, nasce da questa contaminazione, esaltando le potenzialità tecnologiche della rappresentazione, facendo della tecnologia, l'esplicito strumento di indagine sia nella fase ideativa, della ricognizione, sia in quella in cui questa fase si materializza, in maniera tangibile, con la ri-produzione fisica dei risultati: il modello, estensione fisica della techne, architettura della forma. Il presupposto è stato quello di considerare il Disegno in Architettura, come loghía del progetto stesso, come strumento volto a decostruire il significato originale dell'opera architettonica, spogliandola delle funzioni reali e assoggettandola alla pura forma come paradigma di una più ampia visione del sistema architetturale contemporaneo. In questa ottica, la dissoluzione topica dell'archetipo avviene rappresentando la sintesi morfologica attraverso l'impronta della città, un progetto di riconoscimento disvelato attraverso la sua rappresentazione. Questa idea di impronta è proiettata verso il riconoscimento della materialità della forma architettonica, come struttura residuale che nel corso del tempo viene accolta nel tessuto della natura, forma generatrice di forma [Ginex 20 I4].

In termini operativi, le potenzialità tecnologiche derivanti dall'utilizzo di macchine a controllo numerico, quali fresatrice e pantografo, hanno consentito di trasferire le informazioni acquisite nella fase del ri-disegno, sulla superficie bidimensionale di un pannello. Una incisione, una traccia, una impronta. Nel caso del lavoro su Shibam, un pannello di valcromat in fibra di legno. Si procede, successivamente, ad una operazione di svuotamento, opposta all'estrusione. Un'operazione analoga alla scultura, dove il 'disvelamento' della forma avviene per sottrazione, rivelandone l'essenza. Un approccio Heideggeriano, per il quale la parola techne, intesa come produzione, attiene il 'disvelamento' della verità, la stessa che attraverso la pittura, ad esempio, l'artista rivela sulla tela.

Oltre al saper fare, quindi, il saper vedere è quello che consente di ri-conoscere la verità, l'essenza, la più duratura delle scritture. In questo senso, quindi, non c'è alcuna astrazione tecnologica e/o digitale che possa sopraggiungere al valore iconico e simbolico di un progetto attraverso la sua materializzazione fisica (in scala); il modello architettonico come disvelatore di verità.

\section{Note}

[I] La ricerca è frutto di un lavoro comune, riporta gli esiti delle elaborazioni sviluppate all'interno del Corso Integrato di Disegno e Rilievo dell'Architettura, condotto dal prof. Gaetano Ginex, con arch. Francesco Trimboli, arch. Sonia Mercurio, arch. Francesco Stilo, della Università Mediterranea di Reggio Calabria, a.a. 2019/2020, e con la collaborazione dell'Ebanisteria Angelo Cavallaro per il modello analogico della città. L'introduzione ed il paragrafo II Disegno, la Rappresentazione sono da attribuire a Gaetano Ginex; il paragrafo Morfologie dal fango è da attribuire a Sonia Mercurio; II paragrafo Prototipi Urbani. II Rinascimento tecnologico della Rappresentazione è da attribuire a Francesco Trimboli.

[2] Consideriamo l'icona, lo studio della configurazione fisica dei manufatti dello spazio urbano nella loro completezza formale. Quindi una visione percettiva congruente all'immagine complessiva e alle immagini particolari di ogni sistema urbano.

[3] Dall'intervista a Vittorio Gregotti di Francesco Erbani, La Repubblica, 12 luglio, 2017.

[4] 'Digitale': agg. [dal lat. digitalis, der. di digitus «dito»]. Del dito, delle dita; fatto, compiuto con le dita: <https://www.treccani.it/ vocabolario/digitale I/> (consultato il 20 marzo 2021). 


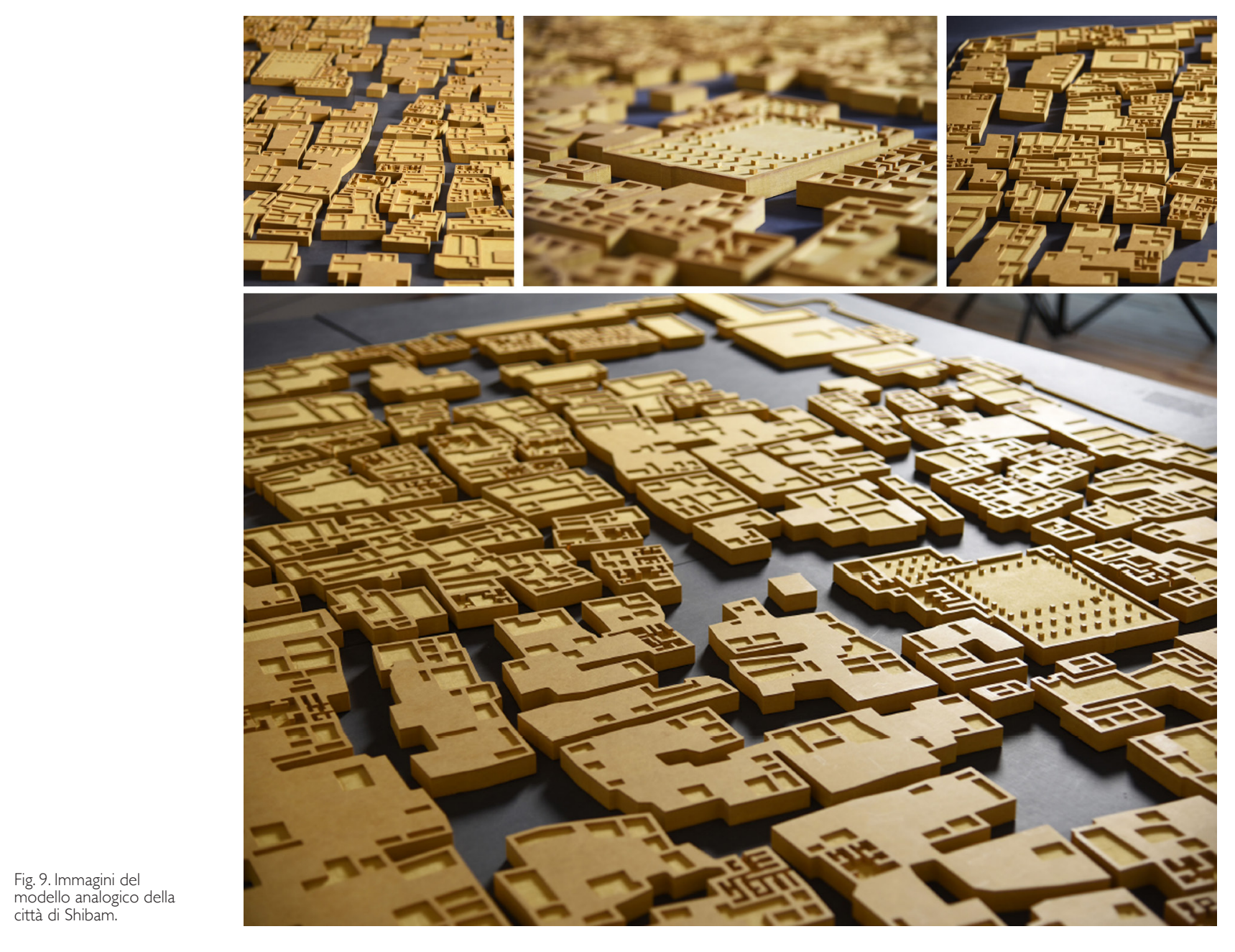

Riferimenti bibliografici

Ajroldi C. (20 14). La ricerca sui centri storici, Giuseppe Samonà e il Piano Programma per Palermo. Roma: Aracne Editrice. Breton J. F., Darles C. (1980). Shibam. In Storia della Città. n. I4, pp. 63-86.

Ginex G. (20 I4). Lasciar impronte, conservar tracce. In P. Belardi et al. (a cura di). Impronte, atti del seminario di studi. Roma: ARTEGRAFICA PLS s.r.l.

Ginex G. (2017). Nefta e le città oasi di Tamerza, Mides e Chebika. Città prima delle sabbie. Reggio Calabria: Iriti.

Petruccioli A. (2007). After Amnesia, Learning from the Islamic Mediterranean Urban Fabric. Bari: ICAR.

Samonà G. (1975). L'unità architettura urbanistica. Scritti e progetti 1929 1973. Milano: Franco Angeli.

Stark F. (1936). The Southern Gates of Arabia. A Journey in the Hadhramaut. New York: E.P. Dutton \& Co, p. 185.

\section{Autori}

Gaetano Ginex, Università Mediterranea di Reggio Calabria, ginex@unirc.it

Francesco Trimboli, Università Mediterranea di Reggio Calabria, francesco.trimboli@unirc.it

Sonia Mercurio, Università Mediterranea di Reggio Calabria, sonia.mercurio@unirc.it

Per citare questo capitolo: Ginex Gaetano, Trimboli Francesco, Mercurio Sonia (2021). Il caso della città di Shibam nello Yemen del Sud. Conoscenza e monitoraggio avanzato del patrimonio culturale/ The case of the City of Shibam in South Yemen. Knowledge and advanced monitoring of Cultural Heritage. In Arena A., Arena M., Mediati D., Raffa P. (a cura di). Connettere. Un disegno per annodare e tessere. Linguaggi Distanze Tecnologie, Atti del $42^{\circ}$ Convegno Internazionale dei Docenti delle Discipline della Rappresentazione/Connecting. Drawing for weaving relationship. Languages Distances Technologies. Proceedings of the $42^{\text {th }}$ International Conference of Representation Disciplines Teachers. Milano: FrancoAngeli, pp. 1669 - 1688. 


\title{
The Case of the City of Shibam in South Yemen. Knowledge and Advanced Monitoring of Cultural Heritage
}

\author{
Gaetano Ginex \\ Francesco Trimboli \\ Sonia Mercurio
}

Abstract

The work presented is closely linked to the attempt to apply and experiment the techniques of digital design and modeling aimed at the knowledge and protection of cultural heritage, with the aim of reflecting on how, in architecture, the sign is the tangible expression of diagnostic process leading to the essence of things; revelator of truth, of forms before becoming morphologies. The study focuses on the morphological plot of the city of Shibam, in the area of South Yemen, a formal archetype which, in the integration of its parts, is one of the most iconic examples of the contemporary architectural system. With reference to the Goals defined by the 2030 Agenda, the theme is linked to Goal I I:"Creating cities and human settlements inclusive, safe, long-lasting and sustainable" and in particular Goal 1 1.4: "Strengthening commitments to protect and safeguard cultural heritage of the world and natural heritage ". In this perspective, the methodological process adopted indicates the use of equipment with archaeological and architectural purposes for the survey of walled cities and fortresses in dangerous areas, whose general objective is to restore the identity of the peoples.

Keywords

archetype, survey, urban morphology, monitoring, heritage.

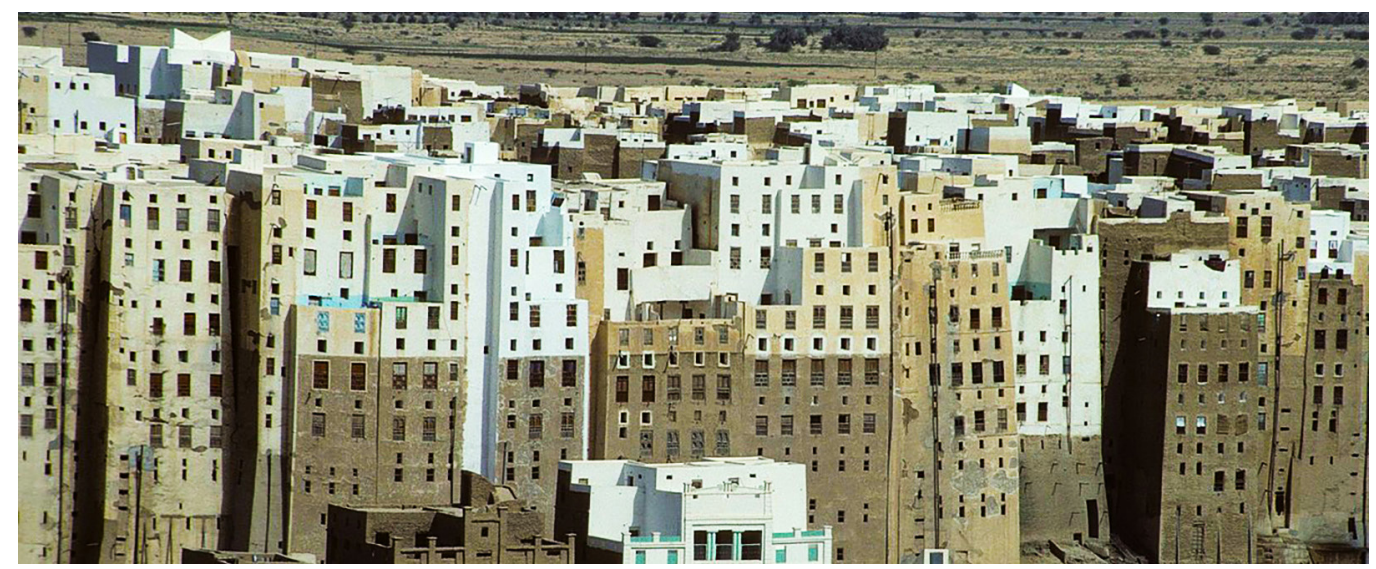


"The morphology of the city is originated from the parts that constitute the signs of its global entity and is specified for successive interrelations of increasingly particular elements according to an interactive process of special cut in function of the relation of morphological associability between place and type of building"

[Samonà 1975]

The work presented [I] concerns the redesign of the main architectural features and the study of the constituent processes and morphological invariants which occur in the cities built near highly sensitive environments and subject to war events that compromise their continuity, with particular reference to the city of Shibam in the South Yemen area. Our goal was to experiment and apply digital design techniques aimed to the knowledge and protection of architecture in a desert environment, of high cultural interest by digital reconstruction in these territories where surveys in presence are difficult to be made and, for various reasons, are dangerous.

The urban tissue of the city of Shibam has a morphological configuration of high figurative value. It's a fragile image for its morphological integrity and physiognomically represents a form of human wisdom. The study is based on highlighting this beauty complexity articulated historically as 'formal archetype' as a stable, immutable and universal settlement principle.

Majestic for its architecture and its position is the urban structure in which it is evident the attempt of survival that, like all civilizations formed in contact with the desert, are marked by the almost biological need to circumscribe the 'space of appropriation' inside a fence that in Islam becomes the figurative matrix of architecture, city and territory.

The structure of the town center must be continuously revealed so as to reveal through sections, profiles, plants, digital models, beyond the variants also homogeneities and stratifications occurred over time that identify at the end of the reading and representation process an image defined as 'icon' [2] or as a deep image that places the space system of Shibam within a set of formal and substantial meanings that coagulate in the final image of the city [Ajroldi 20I4].

The unitary morphological structure consists of the building tissue and the tissue of the voids shared in their complementarity by the magma of the types. A mixture of empty and full spaces, 'intimate' systems of built space, which reveal the relationships of morphological and typological dependence that, the architectural elements at various levels of organization, have among themselves. All the architectural elements are presented in the system of built spaces compact and integral with each other. The typology preserves the essential and original almost archetypal integrity of the relations of solidarity between the space systems that follow one another in the development of morphology.

Morphology, instead, is a set of spatial relations linked by interdependence in a topologically oriented set [Petruccioli 2007]. All the existent architectures, in fact, contribute to create, in their integration, a morphological urban reality and an image of city iconically and universally recognizable.

\section{The Drawing, the Representation}

We started from the analysis of the constitutive characters and the geometric-spatial relationships of the small morphologies of the urban tissues, identifying morphological parts consistent with each other, architectural and invariant elements, deconstructing the unitary system and then recomposing it as a single system.

The stratifications and morphological transformations that have taken place over time have been highlighted with particular attention to the traditional living tissue of the Medina.

Finally, the research has attempted to identify, on the scale of individual homes, their distinctive characteristics so as to reconstruct their physiognomic identity through a digital 'model' that would return an overall social and cultural spatial meaning. 
This has been possible through the study of the general physical structure of the settlement, the study of volumes, the study of the overall form deconstructing it in minimal units as "dynamic" configurations analyzed as formal geometries of minimal sets intended as models of urban parts, in order to lead them to overall shapes in a habitat understood as 'total environment'.

The drawing analyzes this particular condition through a careful approach to the total work as a "document" that becomes such through the digital measurement and restitution of the data that define all the architectural spaces of the city. The goal reached in the digital restitution of the model of the city, highlights the relationship that exists between the organization of the basic 'form', the house, dar-al to Islam, the particular typological settlement that develops in height that builds the 'morpho-logos' and the rest of the built, identifying the repetitive characters that, at the end of the growth process, 'build' the unique and unitary image of the city, in a continuous relationship between simple form and overall image of the urban system enclosed within a fence ideally 'eternal' and impassable.

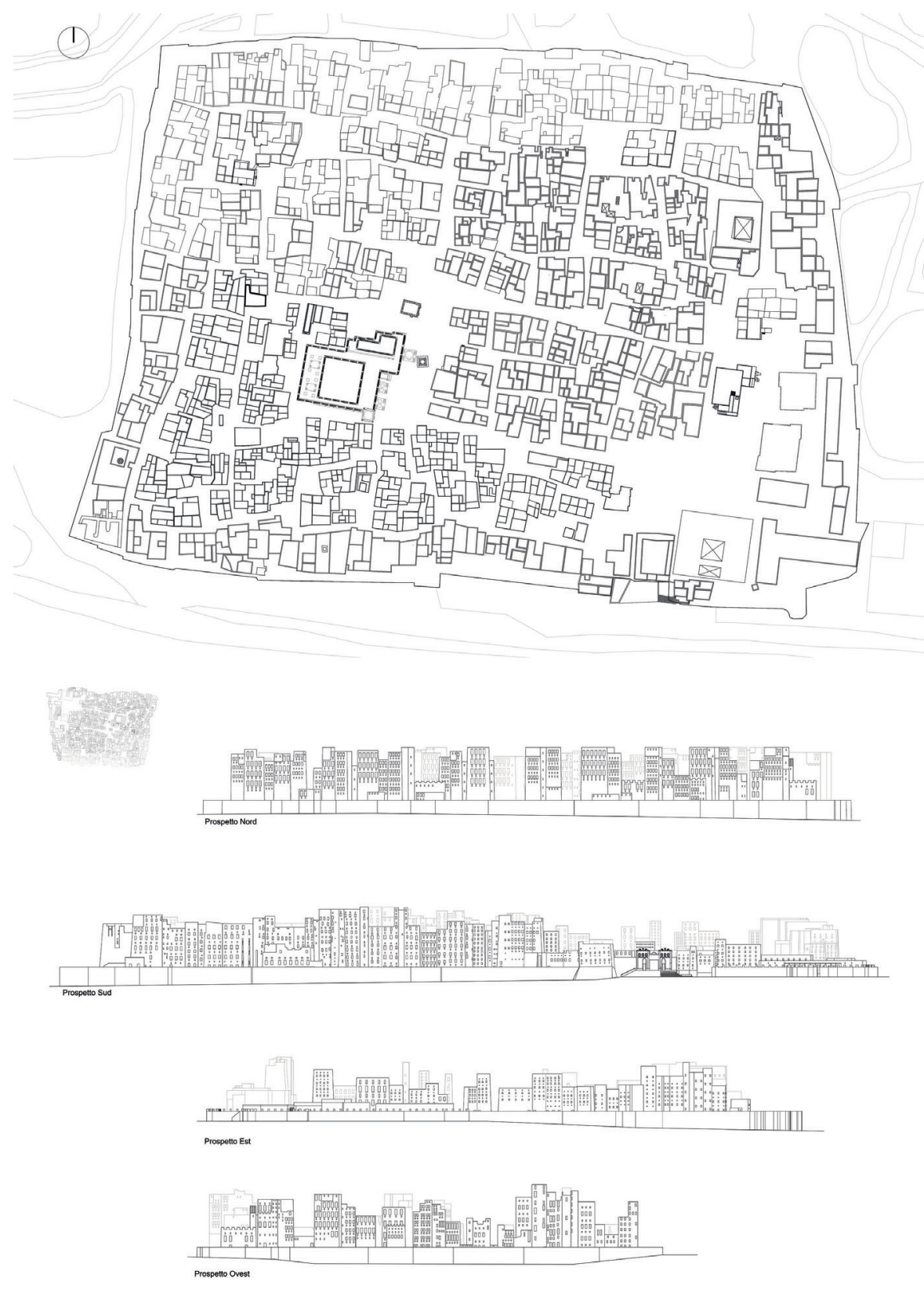


Fig. 2. Axonometries exploded of the city of Shibam.
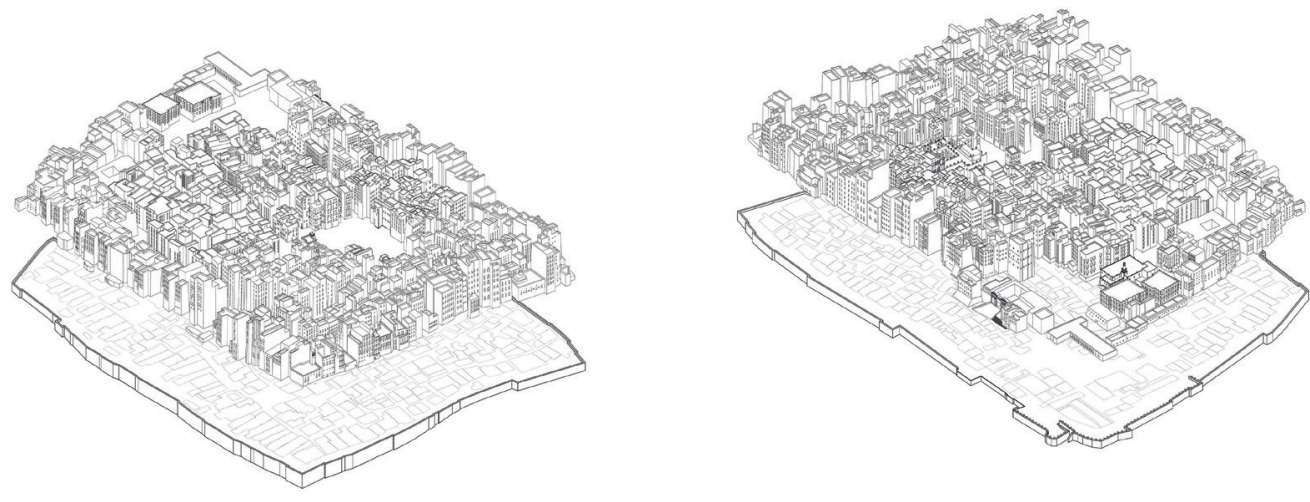

\section{Morphologies from the mud}

The exceptional universal value recognized by UNESCO to the city of Shibam, only partially returns the rarity of this urban structure. Shibam, the city of mud, seems one of those impossible places, an interruption of the desert plot that gives rise to an extraordinary as complex urban morphology.

It is certainly, among the oldest and best preserved examples of urban planning based on an aggregative principle that has generated a system of high urban density, defined, however, according to the axis of verticality, rather than horizontality.

Perched on a rock spur of the Wadi Hadramaut, the city built "by the hands of giants for ancient gods-like kings"'[Freya 1936, p. 1 85], developed on an almost rectangular plan, fortified by a wall about 330 meters long by 240 meters wide; these morphological peculiarities have limited expansion space inside, but have ensured a first line of defense from Bedouin attacks. This defensive origin is also manifested in the dense organization of the buildings, in the compactness of these, as well as in the fragmentation of public space, which appears almost residual, a maze of alleys and widenings.

The contiguity of tower-houses creates walkways in height that act as a link in case of enemy attack and return, to the zenith view, a dense and complex plot with high visual impact that has as skené the vastness of the desert, 'place' base for all settlements studied, in which architecture and nature merge into a single urban system [Ginex 20 I7].
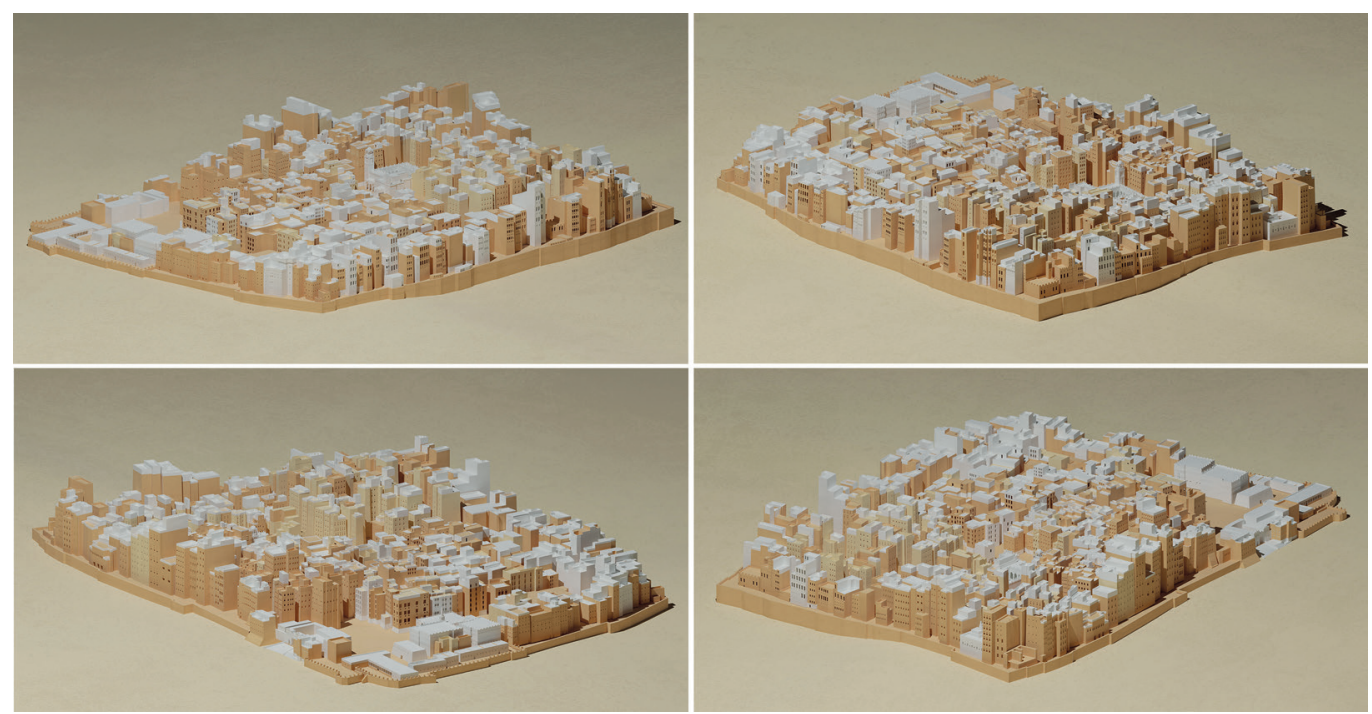

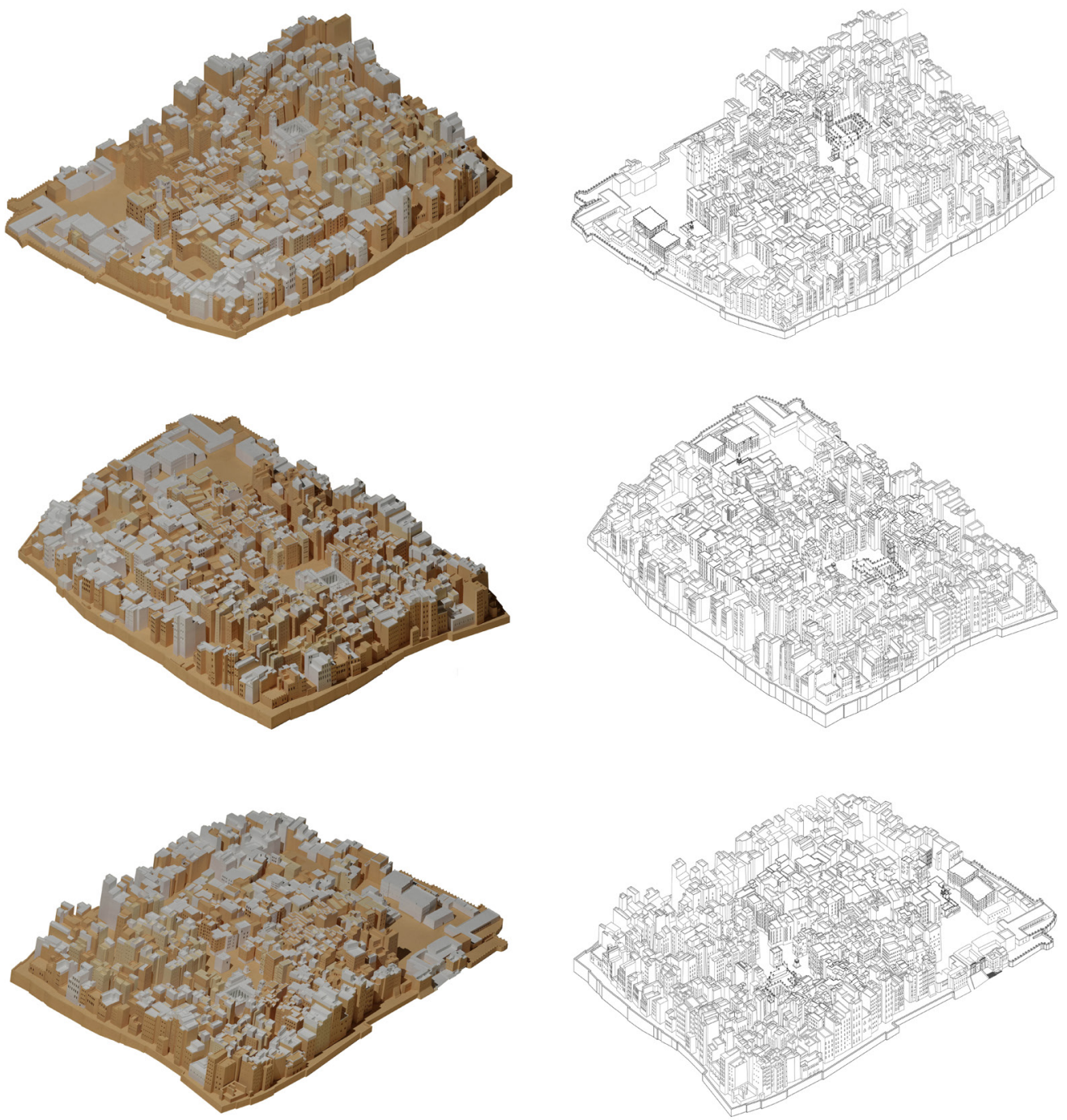

Fig. 4. Axonometric

projections and rendered axonometric views of the
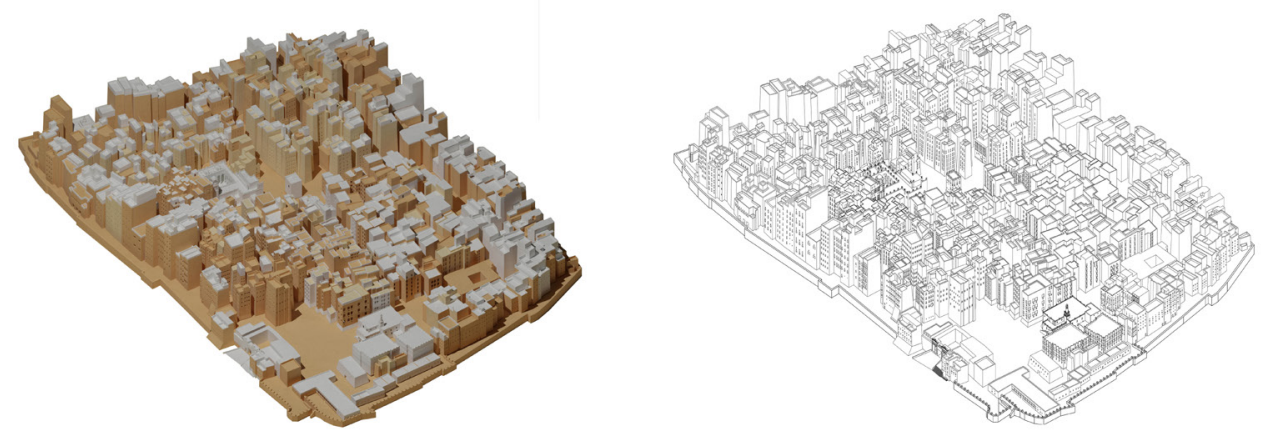
The attempt to study the aggregative and compositional processes of the housing fabric and understand the generative mechanisms, has allowed to identify the urban elements that define the city of Shibam, in such a way:

I. The road network made of alleys and cul-de-sac, which, rather than defining, is defined by the built;

2. The boundary between public and private, very thin, with envelope in height, also;

3. Public space open to all, a diaphragm of small and large places that is composed or fragmented according to the development of the city;

4. "Special" types within the city walls including: six mosques; two madrasas (schools); a private Zawiya (Sufi residence or meeting place); two public buildings; the gate of the city; a health clinic; an administrative complex consisting of four buildings.

From the typological point of view, in reference to the residential tissue, we find common characters to each building, which is usually occupied by a single family. The first and second floors of this, are usually intended as a stable for animals, food storage, or as a shop, place of relationship and exchange with the outside. At this level there is almost no fenestration, or there are small ones, resulting in ventilation problems; this is symbolic evidence of the strong competition that existed between rival families in this region.

The next levels of the towers mark the transition from public to private. The first floor houses one or more main rooms (mahadir), an essentially masculine area. On the next floor, we could find the family meeting room, which is sometimes also used as a bedroom, and above that, the private rooms, including the kitchen, space generally intended for women. The top floor, or mafrah, is reserved for meetings with relatives or friends.

The windows increase to the upper levels of the building, up to the terraces, fully walkable, where the absence of courtyards open on the ground floor is compensated. These tower houses are crowned with battlements and in most cases, these battlements take decorative forms and are whitened with lime, in addition to meeting defensive needs.

The section of these 'mud buildings' is trapezoidal, in fact, the load-bearing walls, decrease their thickness with the development in height of the building itself.

The façades, which are very fragile because they are exposed to factors such as wind and rain, require continuous maintenance that contrasts the erosive process and are repeatedly restored in muddy plasters.

Shibam is, in fact, the archetype that generates modernity, a first and absolute system, which contains the characters of the Islamic city although it is pre-Islamic, which precedes the vertical development of the modern city of the twentieth century, which maintains its original conformation within moenia, deferent to that ancestral expanse of sand.

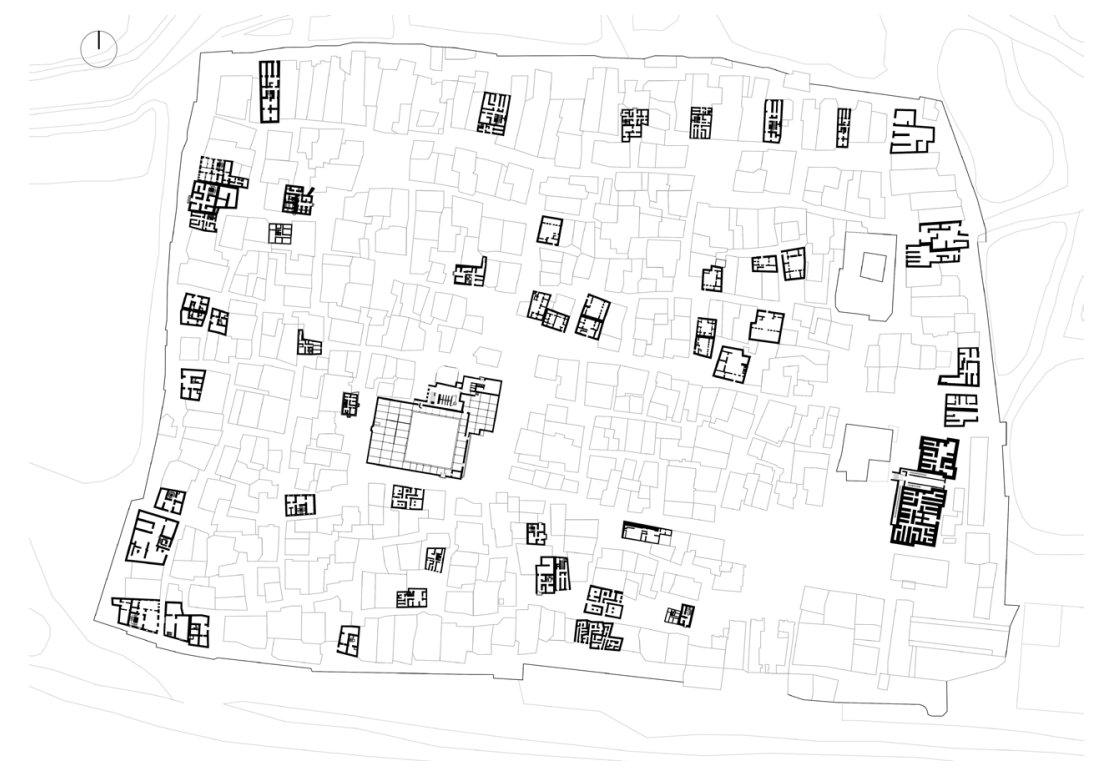



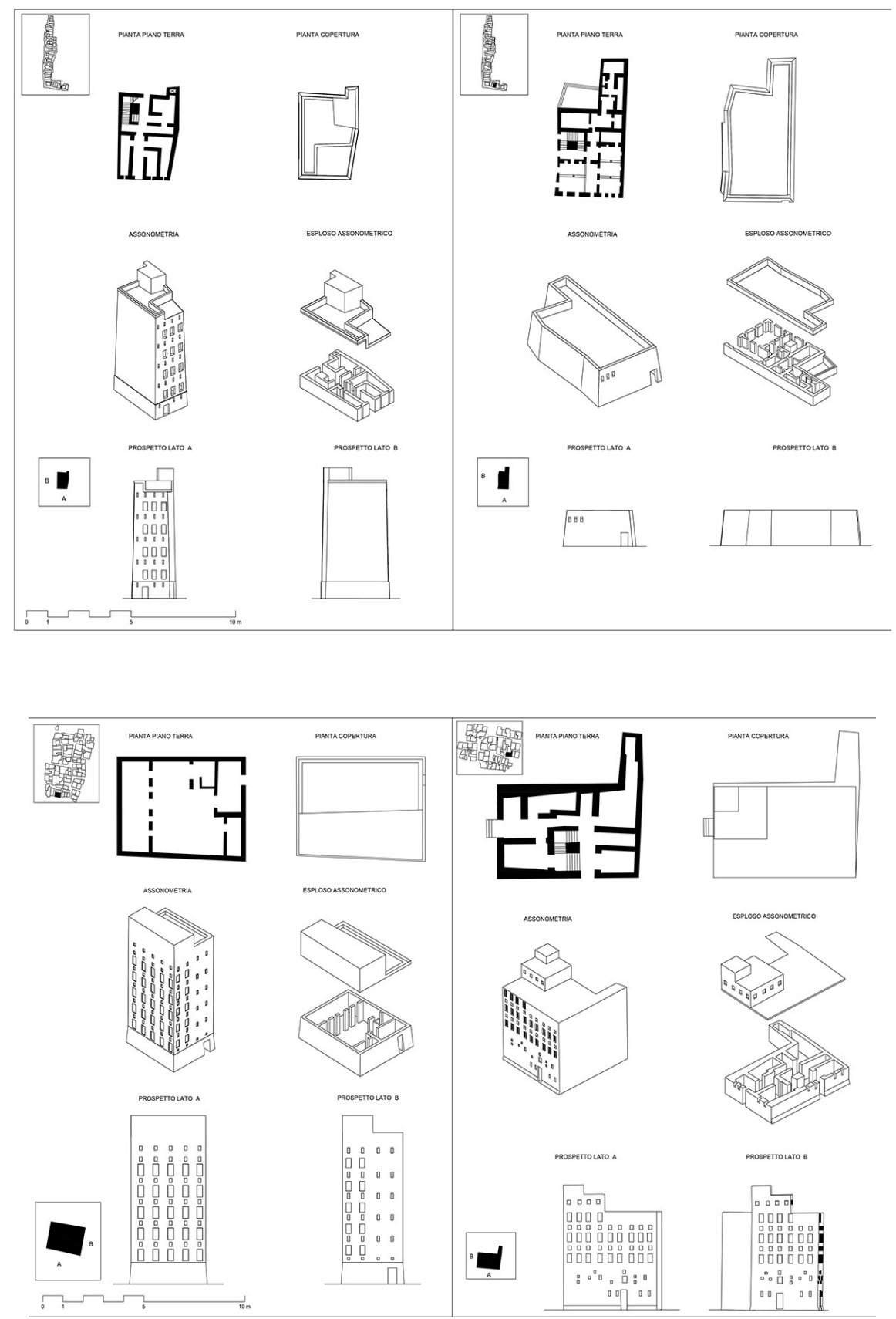

\section{Urban Prototypes. The Technological Renaissance of Representation}

In the contemporary context, in architecture, the model, even if technologically advanced in the construction techniques, becomes the only means and tool with which to alienate and recognize the essence of things, see beyond the visible, beyond the illusory dimension of a screen, limit between knowing how to do and knowing how to see.

In this perspective, technological innovation in architecture refers to the optimal application of the principles and processes that govern its production, becoming the means by which to transfer knowledge, understood as the ability to govern and manage the avant-gardes of a new Technological Renaissance. "With the computer you are precise, but you don't get to the essence of things" [Gregotti 2017] [3]. The consequence is that we turn to a greater quality and scientificity of the processes, which, although representing the evolution 


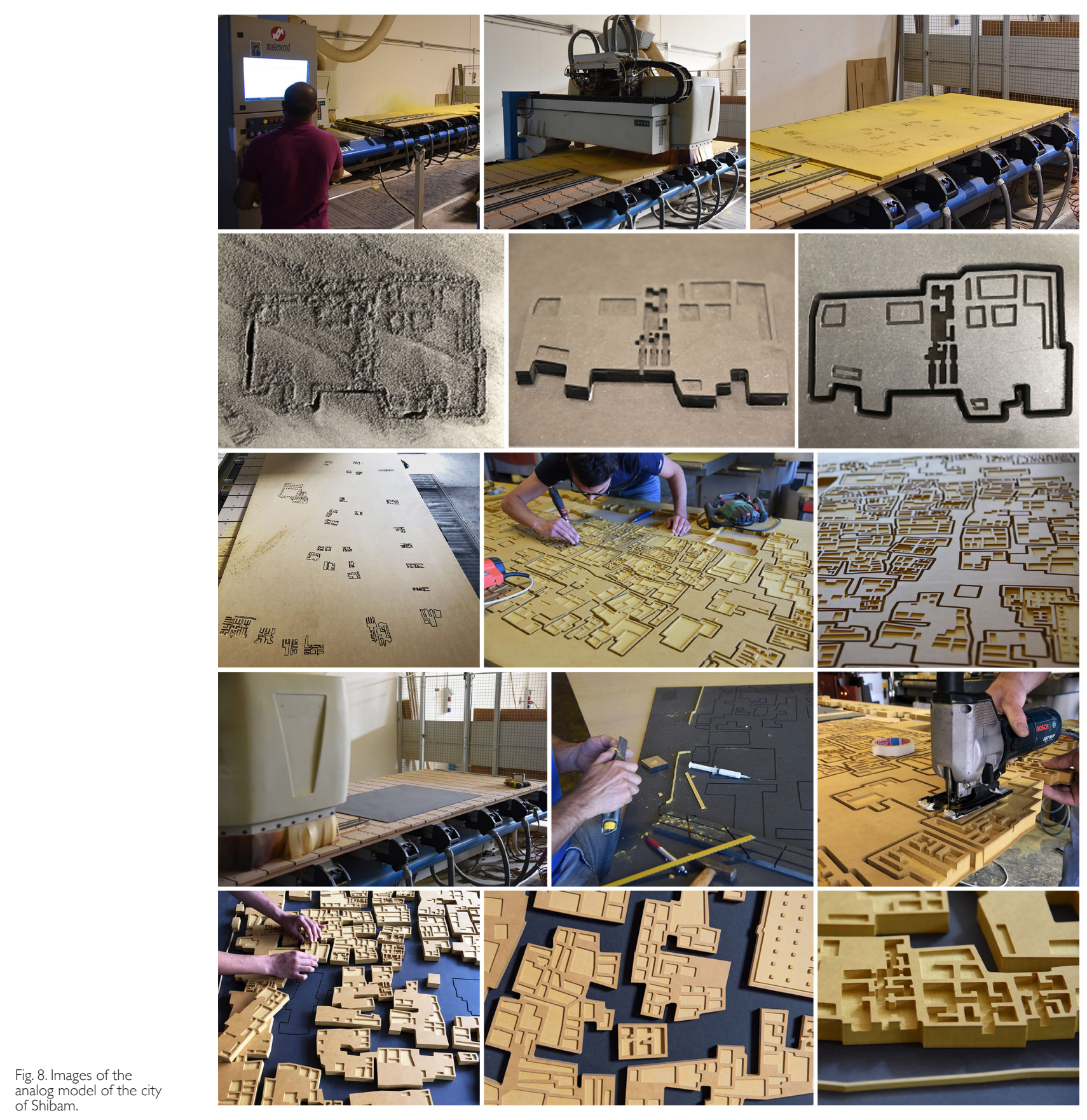


of the technique, is still a mechanical process given by the manipulation of data, of numbers that refer to an action, to a gesture that it pertains to fingers: to type [4]. The etymological analysis of the word technology, techne and loghía refers to knowing how to do, where techne concerns manual skills, action and loghí to the rationalization of the process that leads to the action itself. From this analysis, it is interesting to observe how often, in architecture, technology is synonymous with digital, which is mistakenly recognized as the boundary between practical knowledge and theoretical knowledge, therefore, the tactile manipulation of any digital computer process tends to overlap with the unidirectional one of creativity. In the analogue-digital dualism, understood the first as techne and the second as loghía, the research on representation in architecture, and on drawing in general, intends to shed light on the potential offered by current technologies, which although innovative, must refer to the primitive gesture of communication: the sign (digital or analog). It is therefore no coincidence that the reference to a New Renaissance alludes to the fact that it is precisely in this era that the sign acquires cultural identity before becoming Architecture, becoming a model, maquette, plastic, a tangible expression of the contamination between knowledge and know-how. do, becoming the physical materialization of an idea.

The work on Shibam arises from this contamination, enhancing the technological potential of representation, making technology the explicit instrument of investigation both in the ideative phase, of the recognition, and in the one in which this phase materializes, in a tangible way, with the physical re-production of results: the model, physical extension of techne, architecture of form. The premise was to consider the Drawing in Architecture, as the loghí of the project itself, as a tool aimed at deconstructing the original meaning of the architectural work, stripping it of its real functions and subjecting it to pure form as a paradigm of a broader vision of the architectural system contemporary. In this perspective, the topical dissolution of the archetype takes place by representing the morphological synthesis through the imprint of the city, a project of recognition revealed through its representation. This idea of imprint is projected towards the recognition of the materiality of the architectural form, as a residual structure that over time is incorporated into the fabric of nature [Ginex 2014], a form generating form.

In operational terms, the technological potential deriving from the use of numerical control machines, such as milling machines and pantographs, made it possible to transfer the information acquired during the re-design phase onto the two-dimensional surface of a panel. An engraving, a trace, a footprint. In the case of the work on Shibam, a wood fiber valcromat panel. We then proceed to an emptying operation, opposite to the extrusion. An operation similar to sculpture, where the unveiling of the form takes place by subtraction, revealing its essence. A Heideggerian approach, for which the word techne, understood as production, concerns the unveiling of the truth, the same that through painting, for example, the artist reveals on the canvas.

In addition to knowing how to do, therefore, knowing how to see is what allows you to reknow the truth, the essence, the most lasting of scriptures. In this sense, therefore, there is no technological and / or digital abstraction that can reach the iconic and symbolic value of a project through its physical materialization (to scale); the architectural model as a disclosure of truth.

\section{Notes}

$[\mathrm{I}]$ The research is the result of a common work, reports the results of the elaborations developed within the Integrated Course of Drawing and Survey of Architecture, by prof. Gaetano Ginex, with arch. Francesco Trimboli, arch. Sonia Mercurio, arch. Francesco Stilo, of the Mediterranean University of Reggio Calabria, a.y. 2019/2020, and with the collaboration of the Angelo Cavallaro Ebanisteria for the analog model of the city. The introduction and the paragraph The Drawing, the Representation are to be attributed to Gaetano Ginex; the paragraph Morphologies from mud is to be attributed to Sonia Mercurio; the paragraph Urban Prototypes. The Technological Renaissance of the Representation is to be attributed to Francesco Trimboli.

[2] We could consider the icon, the study of the physical configuration of the artifacts of urban space in their formal completeness. Thus a perceptive vision congruent to the overall image and to the particular images of each urban system.

[3] From the interview with Vittorio Gregotti by Francesco Erbani, La Repubblica, July 12, 2017.

[4] 'Digitale': agg. [by lat. digitalis, der. to digitus «dito»]. Of the finger, of the fingers; done, done with the fingers: <https://www. treccani.it/vocabolario/digitalel/> (accessed 2021, March 20). 


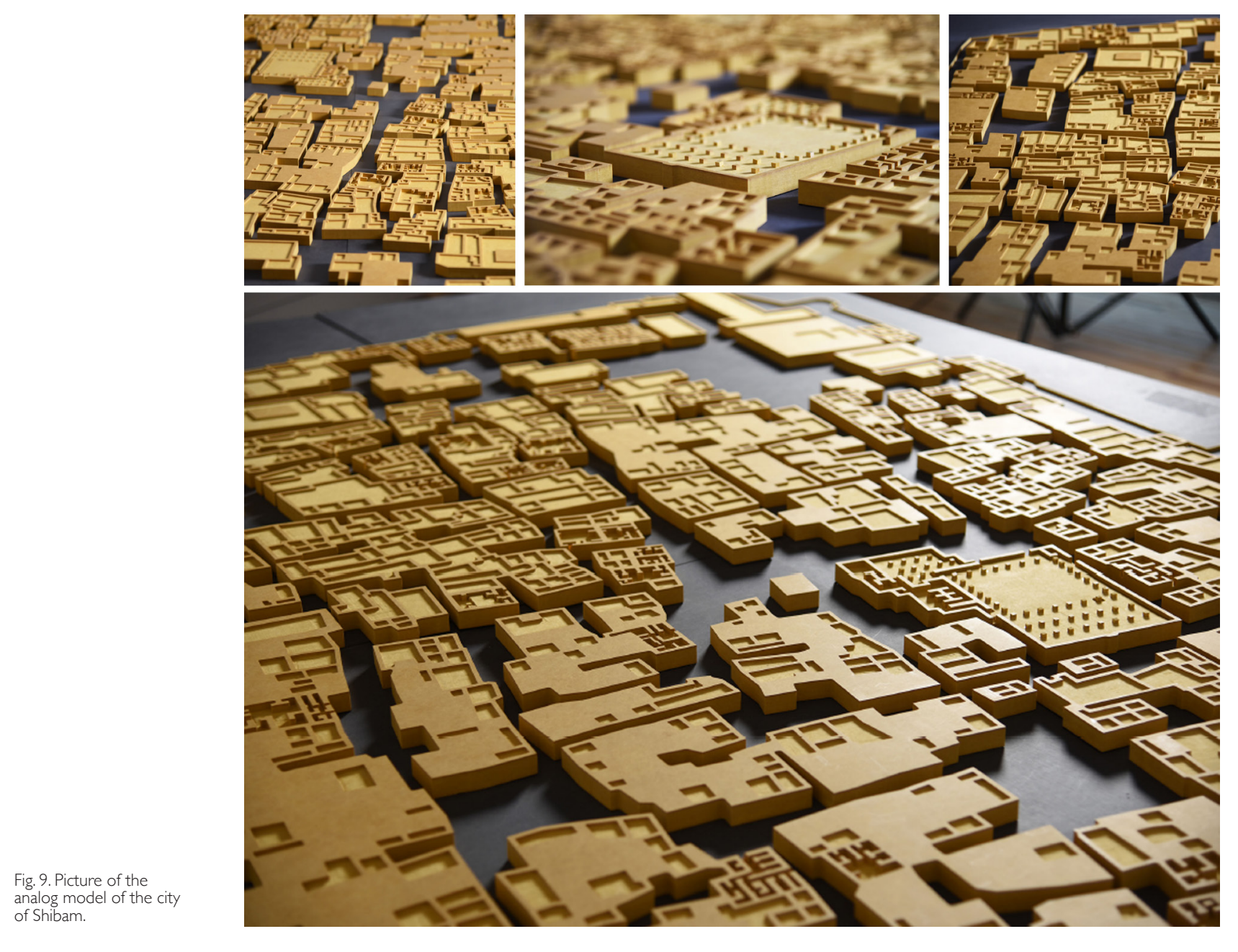

References

Ajroldi C. (20 14). La ricerca sui centri storici, Giuseppe Samonà e il Piano Programma per Palermo. Roma: Aracne Editrice. Breton J. F., Darles C. (1980). Shibam. In Storia della Città. n. I 4, pp. 63-86.

Ginex G. (20 I4). Lasciar impronte, conservar tracce. In P. Belardi et al. (a cura di). Impronte, atti del seminario di studi. Roma: ARTEGRAFICA PLS s.r.l.

Ginex G. (2017). Nefta e le città oasi di Tamerza, Mides e Chebika. Città prima delle sabbie. Reggio Calabria: Iriti.

Petruccioli A. (2007). After Amnesia, Learning from the Islamic Mediterranean Urban Fabric. Bari: ICAR.

Samonà G. (1975). L'unità architettura urbanistica. Scritti e progetti 1929 1973. Milano: Franco Angeli.

Stark F. (1936). The Southern Gates of Arabia. A Journey in the Hadhramaut. New York: E.P. Dutton \& Co, p. 185.

\section{Authors}

Gaetano Ginex, Università Mediterranea di Reggio Calabria, ginex@unirc.it

Francesco Trimboli, Università Mediterranea di Reggio Calabria, francesco.trimboli@unirc.it

Sonia Mercurio, Università Mediterranea di Reggio Calabria, sonia.mercurio@unirc.it

To cite this chapter. Ginex Gaetano, Trimboli Francesco, Mercurio Sonia (2021). II caso della città di Shibam nello Yemen del Sud. Conoscenza e monitoraggio avanzato del patrimonio culturale/ The case of the City of Shibam in South Yemen. Knowledge and advanced monitoring of Cultural Heritage. In Arena A., Arena M., Mediati D., Raffa P. (a cura di). Connettere. Un disegno per annodare e tessere. Linguaggi Distanze Tecnologie. Atti del $42^{\circ}$ Convegno Internazionale dei Docenti delle Discipline della Rappresentazione/Connecting. Drawing for weaving relationship. Languages Distances Technologies. Proceedings of the $42^{\text {th }}$ International Conference of Representation Disciplines Teachers. Milano: FrancoAngeli, pp. 1669 - 1688. 